\title{
Popular Luxury in Southeastern Europe in the Long Eighteenth Century: A Case-Study of Italian Ceramics and Ottoman Greek Clients
}

\author{
Artemis Yagou \\ Deutsches Museum, Munich, Germany \\ artemis@yagou.gr
}

\begin{abstract}
In late eighteenth-century Ottoman Epirus (today northwestern Greece), novel and pleasurable objects expressed on a material level the rise of new mentalities. We discuss specifically the ceramic trefoil jugs with Greek verses manufactured in Pesaro, Italy, by the firm of Casali and Callegari and its successors. These wine jugs follow a pre-existing formal typology and bear painted decoration; their particularity is that they are also inscribed with verses written in Greek, as they were produced following commissions by merchants from Epirus. This region boasted centers of commerce, wealth, and education of an emerging middle class; the economic power of this rising Greek bourgeoisie was combined with deepening ties with Europe, intellectual growth, and the strengthening of a distinct identity. We argue that these jugs are examples of popular luxury and the commissioning individuals were knowledgeable and proactive consumers exhibiting a growing confidence and indeed a new awareness with political connotations.
\end{abstract}

\section{Keywords}

consumption - popular luxury - ceramics - Greece - Epirus - Ioannina - Italy - Pesaro

\section{Introduction}

Every culture is "dependent on its artefacts for its survival and self-realization," and their analysis and interpretation is a "primary humanistic study." The

1 E. McClung Fleming, "Artifact Study: A Proposed Model," Winterthur Portfolio 9 (1974): 153. 
trefoil tin-glazed earthenware jug with Greek verses, a type of object produced in Italy and used by Ottoman Greek clients during the last decades of the eighteenth century and in the early stages of the nineteenth, is a fascinating example of the hitherto relatively under-researched material culture of the early modern Balkans. The analysis that follows attempts to unravel the complex interrelations between such a simple object and wider sociocultural developments. The overall aim is to contribute to understanding the range and complexity of social interactions within that region in a time period that is considered crucial and formative in relation to subsequent sociopolitical developments. ${ }^{2}$ The object-based approach employed is founded on the systematic study of material artifacts from the past, proceeding outwards towards wider circles of contextual information which demonstrate the significance of the object for various stakeholders. When examined methodically and thoroughly, objects tend to surprise us with their complexity; they also resist easy interpretation. The more objects are examined, the more different aspects are being discovered, exposing "patterns, relationships, and complexities that would otherwise remain hidden."3 Object-based, design-historical discourse deals with artifacts and their meanings, which remain fluid and continuously arising in social interactions. The systematic examination and reframing of existing artifacts explores the meanings that emerge or disappear in social processes; new, unexpected, and still unimagined meanings may thus be produced. ${ }^{4}$

\section{The Pesaro-Made Epirote Trefoil Jug with Greek Verses}

A jug held at the British Museum, London, [Figure 1], is described on the institution's website as follows: "Jug with pinched lip, handle formed of two strips of clay, spreading foot; pale earthenware color covered with a presumed tin-glaze; painted with a design of flowers and leaves and dashes on the handle;

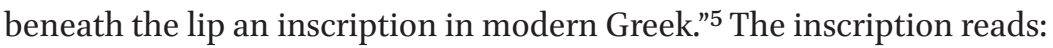

2 Petros Pizanias, I istoria ton Neon Ellinon apo to 1400 eos to 1820 (Athens, 2014).

3 Laurel Thatcher Ulrich et al., Tangible Things: Making History Through Objects (Oxford, 2005), 20.

4 Klaus Krippendorff, "Designing Design-forsch-ung; not Re-search," Keynote speech, Conference on Practice-Based Research in Art, Design \& Media Art, Bauhaus-University Weimar, December 1-3, 2011; see also Klaus Krippendorff, The Semantic Turn: A New Foundation for Design (Boca Raton, 2006).

5 Jug, British Museum, Museum number 1882, 1016.1, http://www.britishmuseum.org/ research/collection_online/collection_object_details.aspx?objectId=33108\&partId=1 (accessed 


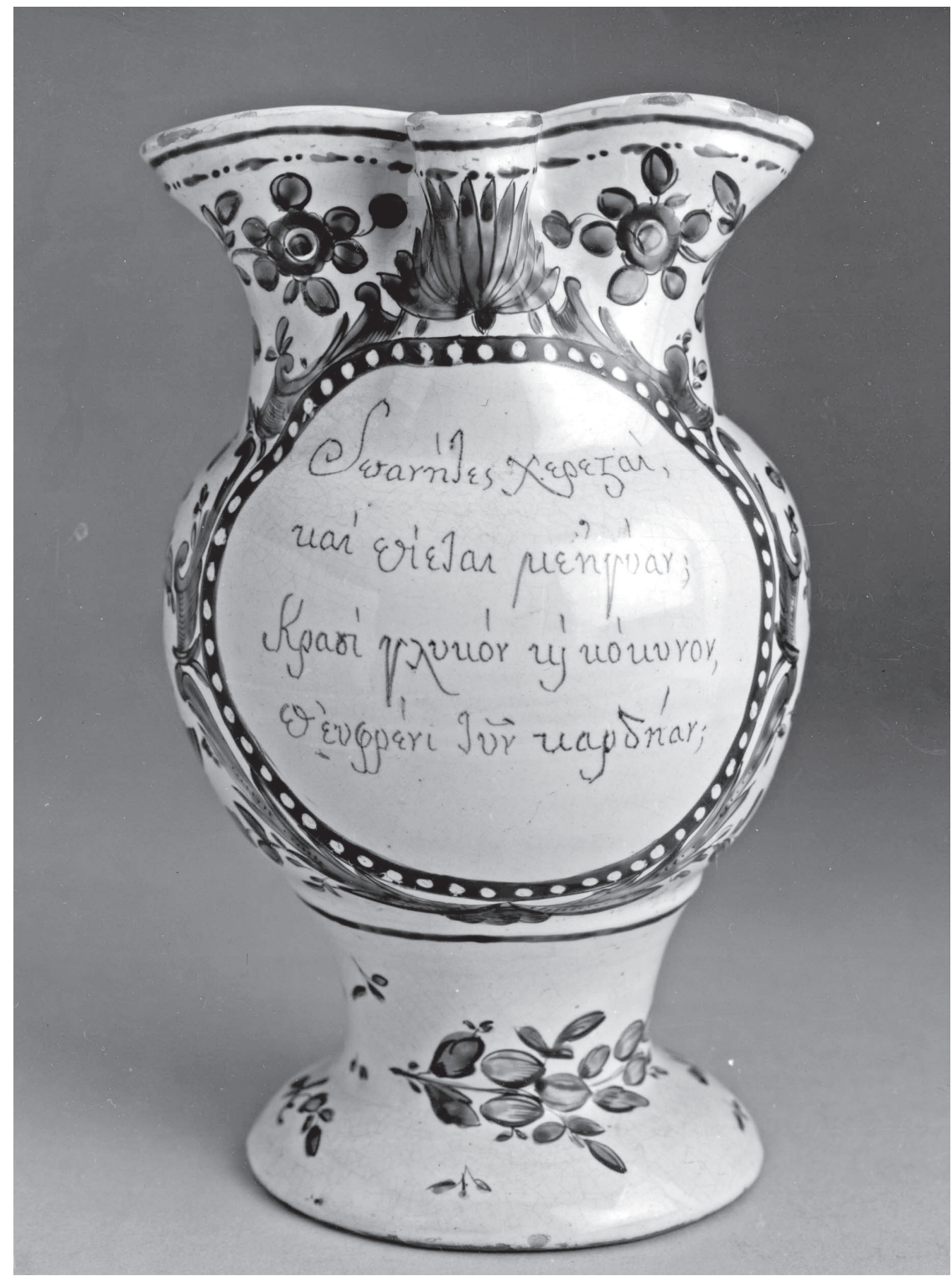

FIGURE 1 Ceramic trefoil jug inscribed with Greek verses, manufactured in Pesaro, late eighteenth to early nineteenth century, British Museum, London. (C) THE TRUSTEES OF THE BRITISH MUSEUM. 
People of Ioannina be joyful

and drink with health

Red and sweet wine

that delights the heart. ${ }^{6}$

The twenty-three centimeter tall jug was made in Pesaro between 1787 and 1810, by the Callegari and Casali firm as indicated by the C. \& C. mark on the bottom; "No 2" most likely indicated the design, thus suggesting a standardized process of quantity production. The item number 8592 from the Benaki Museum in Athens also bears "No 2 C\&C" and a similar text (albeit with several mistakes, attributed to the copying process). ${ }^{7}$

The trefoil jug was typically used as a wine container and takes its name from the leaf-shaped (trefoil) spout which is designed to facilitate pouring of the liquid. ${ }^{8}$ This type of jug provides a fascinating example of the circulation of goods in early modern Europe and specifically in its southeastern regions. Trefoil jugs originating from various regions of Italy (Castelli, Venice, Padua, Pesaro) were being imported and used in southeastern Europe from the late seventeenth century onward, especially on the Aegean island of Skyros. ${ }^{9}$ In the late eighteenth century, there were primarily two types of trefoil jugs produced in large numbers by Italian workshops: in the first one, the surface of the vessel was painted with floral decoration and the Habsburg double-headed eagle [Figure 2]; such designs were meant for the markets on the western Adriatic coast and the German-speaking lands. The design with the double-headed eagle is attributed to the Italian ceramist Giuseppe Bartolucci and was probably created for the first time between 1757 and 1760 in Pesaro. ${ }^{10}$

August 9, 2019). Note that the word "Ioannites" (residents of Ioannina) is incorrectly transcribed as "Spanites" (residents of Spanos).

6 Author's translation from the Greek original: "Ioannites haireste/ke piete me ygeian/Krasi glykon kai kokkinon/ p'eufrainei tin kardia." The transliteration of Greek characters follows the system described in Paschalis M. Kitromilides, Enlightenment and Revolution: The Making of Modern Greece (Cambridge, MA, 2013), xv-xvi.

$7 \quad$ Katerina Korre-Zografou, Ta Kerameika tou Ellinikou Chorou (Athens, 1995), 130-131.

8 The trefoil jug typology was widespread temporally and geographically, representing a common, everyday vessel, as indicated by exhibits in the Byzantine and Christian Museum in Athens, the Byzantine Museum of Ioannina, and by miniature trefoil jugs used in eighteenth-century Italian dioramas now kept at the Bavarian National Museum in Munich.

9 Korre-Zografou, Ta Kerameika, 195. Angeliki Chatzimichali, Elliniki Laiki Techni, Skyros (Athens, 1925), 178-179. Eleni Pitari Maioletti, "Spania Antikeimena Evropaikis Technis stin Skyro," Zygos 4 (1973): 6-9.

10 Korre-Zografou, Ta Kerameika, 126-132 and 195-197; and Leon Lorenzo Loreti, Maioliche e terraglie di Pesaro: notizie inedite sulle fabbriche, sui marchi e sui maiolicari (Padova, 1978), 


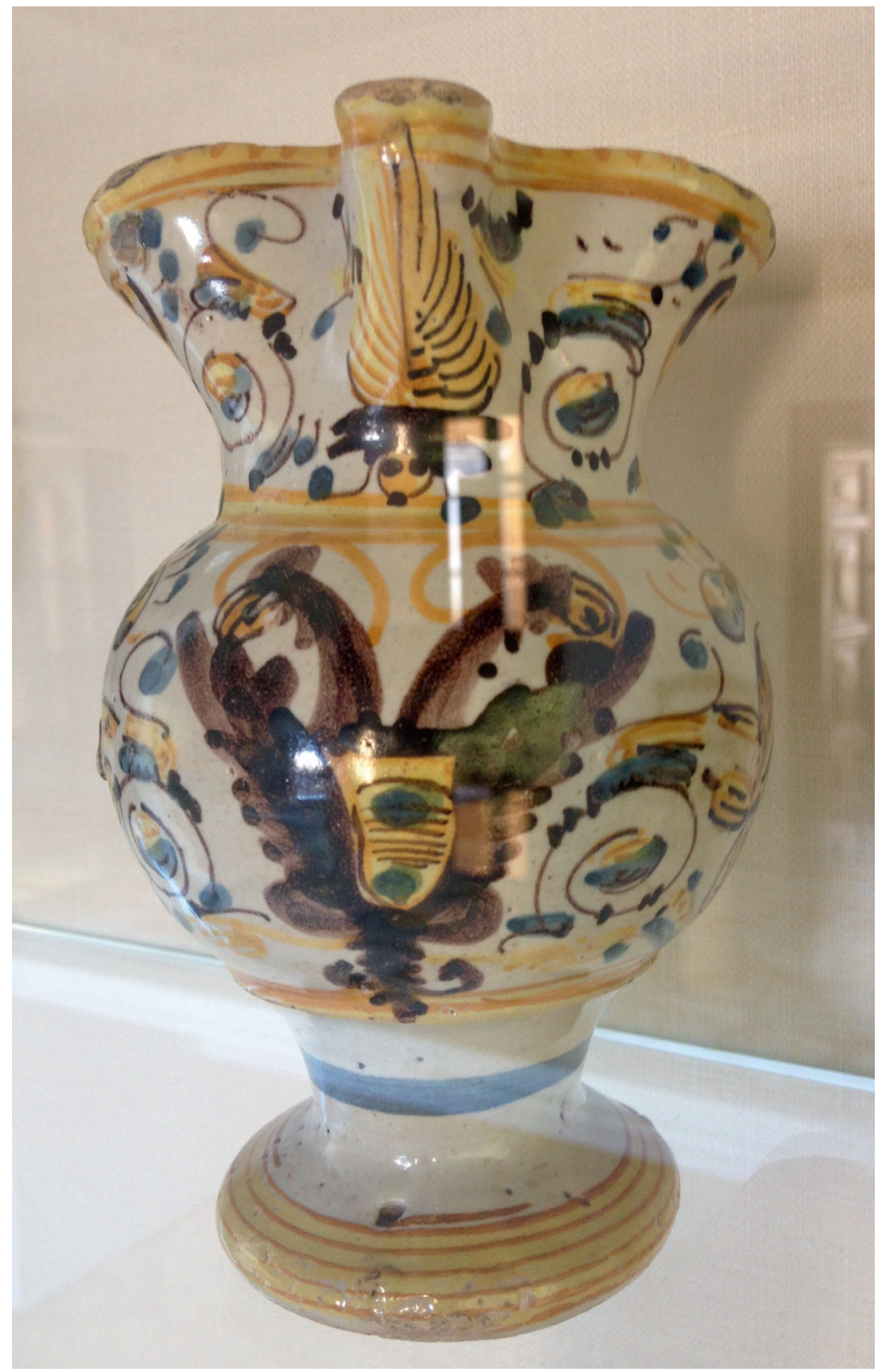

FIGURE 2 Pesaro-made trefoil jug decorated with the Habsburg double-headed eagle, late eighteenth century, Lazaros Koundouriotis Historical Mansion (National Historical Museum), Hydra Island (Greece). PHOTOGRAPH BY THE AUTHOR. 
The second type of jug, to which the aforementioned British Museum item belongs, was the Epirote trefoil jug, named so because it was manufactured in Pesaro specifically for the market of the Epirus region (today northwestern Greece). Like the first type, it has a pinched spout and strap handle, stands on a circular foot and is painted in polychrome; its particularity lies in the fact that it bears Greek verses within a roundel below scrolls and palmettes, surrounded by bouquets of brightly colored flowers and foliage on a circular base. The height is variable, usually between fifteen and twenty-three centimeters, while respectively the base diameter varies between around eight and eleven centimeters. The letters are in black ink, written in typical eighteenthcentury Greek cursive style.

These Pesaro-made jugs are indicative of material conditions of daily life in the region of Epirus, as they are directly related to wine drinking, entertainment, and well-being. The verses may be described as popular poetry of a bacchic content; it is suggested that they were improvised during drinking sessions by the drinkers themselves. ${ }^{11}$ They are related to wine-drinking from various perspectives: as a salutation to fellow drinkers, as a call to drink and enjoy, as a warning against the dangers of excess, or as a hymn to friendship. Their content reflects certain attitudes that were presumably favored by the commissioners: the verses praise work and industriousness, celebrate companionship, castigate inebriation as being detrimental to health and well-being, and acknowledge the joys of life. Arguably, the respective values formed the backbone of the commissioners' success and welfare. At the same time, there are jugs bearing verses referring to debts, thus reflecting the difficulties entailed in financial activities. ${ }^{12}$

45 and image XLIII. In one case, the double-headed eagle has been interpreted as a symbol of the Byzantine Empire, reminiscent of "the recent illustrious past of Hellenism and rekindling the hopes of subjugated Greeks for the realization of the Great Idea," Maria Lada-Minotou, "Antikeimena Istorimena me Ellenika Themata Filotechnimena se Evropaika Ergastiria Kerameikis kai Porselanis," in Sylloges Evangelou Averof: Taxidevontas sto Chrono (Athens, 200o), 234. The previous quote refers to the Great Idea (Megali Idea), whose proponents aspired to unite Greek populations within a single nation-state, with Constantinople as its capital. This is however an anachronism, as the formulation of the Great Idea is attributed to politician Ioannis Kolletis during an 1844 speech. See Richard Clogg, A Concise History of Greece, 3rd ed. (Cambridge, 2014), 46-47. See also Basile Kyriazopoulos and Angele Charitonidou, "Poterie de Pesaro décorée de vers en grec moderne," Faenza 66 (1980): 354.

11 Korre-Zografou, Ta Kerameika, 126-2 and 195-197; and Kyriazopoulos and Charitonidou, "Poterie de Pesaro," 355.

12 M.P. Lambros, "Peri Ipeirotikon Enepigrafon Mastrapadon," Parnassos 7 (1883): 271. 
The different verses painted on the jugs appear in many variations. A jug kept in the Benaki Museum (Athens) has the same text as the British Museum item. ${ }^{13}$ Variations of this four-line verse also appear with the place name "Kalarrytes" replacing "Ioannina," as other jugs kept in the same collection illustrate. ${ }^{14}$ Similarly, three other jugs in that collection bear slightly different verses warning against the dangers of excessive drinking. ${ }^{15}$ This suggests that certain verses may have been particularly popular since they were replicated in multiple copies. Even when the verses on two different jugs are the same, there are regularly small variations, such as the misspelling of ounou, instead of oinou (of wine). ${ }^{16}$ Spelling mistakes or variations in the texts are to be expected from workers with different knowledge of the language or level of education; furthermore, it would be reasonable to take into account unfavorable working conditions in the workshop or time-pressure during the production process. Calligraphic or more accurate texts have been attributed to Greek craftsmen who presumably worked in those workshops. ${ }^{17}$ Furthermore, as far as hand-painted decoration is concerned, although it follows specific designs, these appear slightly different on each jug because of the variable skills of individual artists. Generally speaking, the surviving jugs exhibit standard designs with small variations; quantity production goes hand-in-hand with personalization, resulting in artifacts which are similar but not identical.

Apart from verses addressed specifically to the people of Ioannina and Kalarrytes, personalization also takes other forms: some jugs are marked with initials on the front (for example "KS"), ${ }^{18}$ presumably of the individual who ordered the item. A special case of customization is presented by the jug held in the Benaki Museum with verses in Vlach, a language of Latin origin. ${ }^{19}$ The Greek alphabet is used in this case because Vlach was a spoken language without written records. ${ }^{20}$ This object is related to Christian populations of Epirus who were bilingual (Greek/Vlach); it has been argued that

\footnotetext{
13 Korre-Zografou, Ta Kerameika, 130, figure 218.

14 Ibid., 129, figures 216 and 217. Most of these jugs were intended for the communities of Ioannina and Kalarrytes (now in northwestern Greece), Lambros, "Peri Ipeirotikon Enepigrafon Mastrapadon," 269-270.

15 Korre-Zografou, Ta Kerameika, 130, figures 221, 222, and 223.

16 Ibid., 130, figure 223 in comparison to 221 and 222.

17 Ibid.

18 Ibid., 128, figure 211.

19 Ibid., 130-131 and figure 219.

20 On the first written texts in the Vlach language, including inscriptions on Pesaro jugs, see Mihai Țipău, "Autour des Premiers Textes Écrits en Aroumain," Revue des Études Sud-Est Européennes, XLVIII, 1-4 (2010): 239-253.
} 
these groups possessed a strong, stable, and dominant Greek conscience, while their Vlach identity could be considered as a secondary local identity. ${ }^{21}$ The idiosyncratic jug highlights the complexity and "fluidity of linguistic and ethnic identities" in southeastern Europe during the period under consideration. $^{22}$

The ceramic industry of Pesaro, where these items originated from, had an illustrious history since the Renaissance, reaching its highlight in the sixteenth century. Following a long period of decline that was partly attributed to competition by porcelain from the Far East, the manufacture of pottery was revived around the middle of the eighteenth century. A ceramics factory was initially established by Giuseppe Bertolucci of Urbania in 1757 , but with limited success. In 1763, a new company was established by two ceramicists from Lodi, Antonio Casali (1727-1787) and Filippo Antonio Callegari (1730-1810), assisted by Pietro Lei, a skilled painter from Sassuolo. ${ }^{23}$ The Epirote type of jugs was first created at the factory of Casali and Callegari around 1770. During the course of the eighteenth century the company's production included fine earthenware, sometimes glazed with three firings and decorated with bunches of flowers and roses; these items restored Pesaro to the highest level of towns with a long tradition of ceramic manufacture. ${ }^{24}$ The products with Greek verses originate from that period of rejuvenation of the ceramic industry in Pesaro, as confirmed by the relevant marks under the foot of the jug, such as "C.C." for "Casali and Callegari" and "P.P. Lj." for "Pinse Pietro Lei." The identity of the workshop, as well as numbers corresponding to a specific design (for example No. 2 or No. 12), are typically marked on the base of the jug [Figure 3]. ${ }^{25}$ The period of Antonio Casali and Filippo Callegari (1763-1787) was succeeded by

21 Vassilis Panagiotopoulos, Archeio Ali Pasa, vol. 4 (Athens, 2009), 114. See also: Dimitris Tziovas, "Introduction," in Greece and the Balkans: Identities, Perceptions and Cultural Encounters since the Enlightenment, ed. Dimitris Tziovas (Aldershot, 2013), 6.

22 Tziovas, "Introduction," 4.

23 Giambattista Passeri, Istoria dele pitture in maiolica fatte in Pesaro e ne' luoghi circonvicini, 2nd ed. (Pesaro, 1857); the study was written around $175^{8}$ and published for the first time in 1838. William Chaffers, Marks and Monograms on Pottery and Porcelain (London, 1903), 86. We use the name form "Callegari," which appears to be the most widely used on the objects themselves and in related publications; the name also occasionally appears as "Calegari" or "Caligari."

24 Passeri, Istoria delle pitture, 98-99. The term maiolica is often used for these types of ceramics. See also: Otto von Falke, Majolika (Berlin, 1907), 168; Luigi De Mauri, L'Amatore di maioliche e porcellane (Milano, 1988), 181; Claudio Giardini, Ceramica pesarese nel XVIII secolo: la manifattura Casali e Callegari, 1763-1816 (Ferrara, 1995), 37-38; and Claudio Paolinelli, "Regesto delle Principali Manifatture Ceramiche Italiane dell'Ottocento," DecArt: Rivista di Arti Decorative 7 (2007): 65-68.

25 Chaffers, Marks and Monograms, 86. 


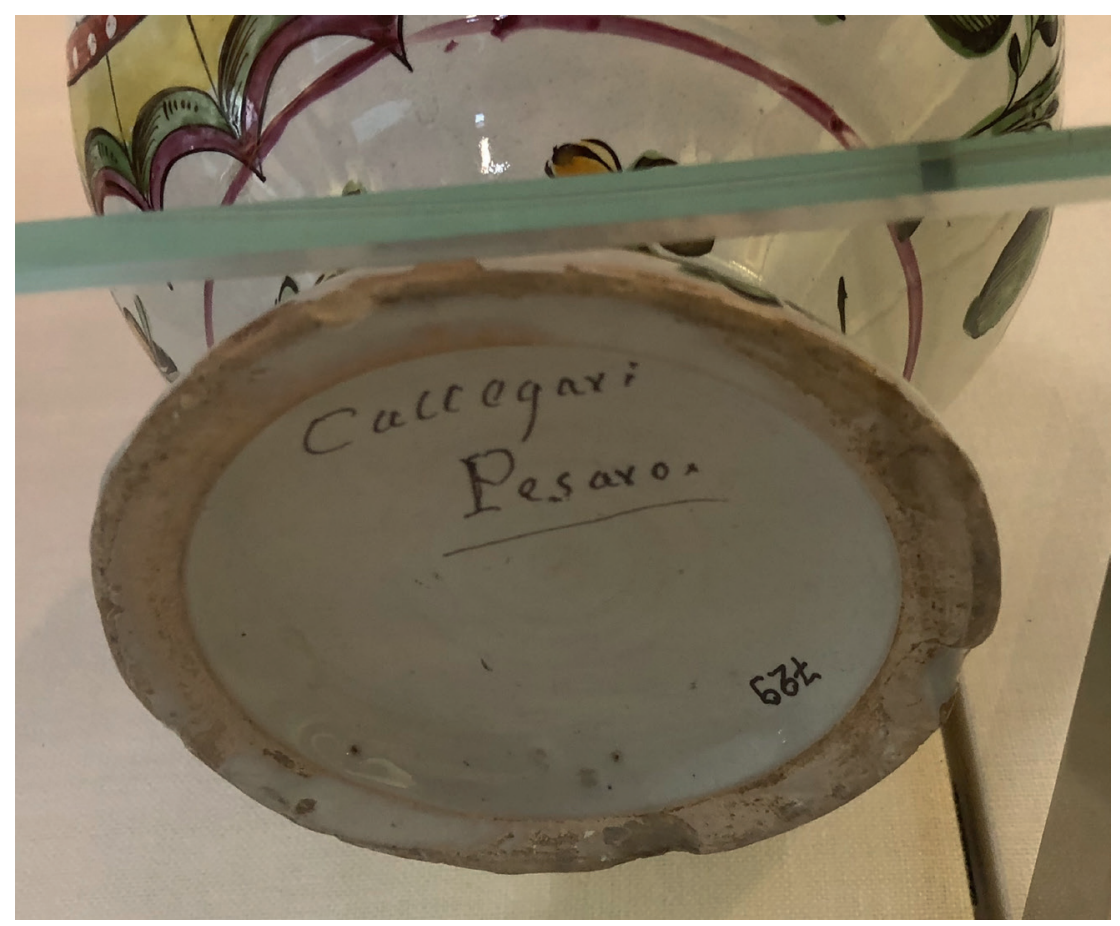

FIGURE 3 Mark of the firm Callegari Pesaro on the base of trefoil jug inscribed with Greek verses, Lazaros Koundouriotis Historical Mansion (National Historical Museum), Hydra. PHOTOGRAPH BY THE AUTHOR.

that of Ippolito Casali and Filippo Callegari (1787-1810), and subsequently of Ippolito Casali and Ignazio Callegari (1810-1816). Later on, the partnership between the two families ceased, and each opened a factory on its own account. Eventually, the Casali works were passed on to someone called Paolucci and were closed in 1849, while the Callegari was transferred to Magrini and Co. which reopened it in 1870.26

Jugs from Pesaro were exported in large quantities to Epirus, various islands of the Aegean, and Anatolia from the port of Ancona, close to Pesaro, through intermediary Greek traders, who frequented the nearby annual fair

26 Loreti, Maioliche e terraglie, 29-63; Charles Drury E. Fortnum, Maiolica: A Historical Treatise on the Glazed and Enamelled Earthenwares of Italy (London, 1896), 155; and Giuseppe Marino Urbani de Ghelthof, Notizie sulla ceramica italiana (Rome, 1889), 205. An online search in the state archives of Pesaro for surviving documents of the Casali and Callegari firm did not yield any results. 
of Senigallia, although relevant information remains limited. ${ }^{27}$ It appears that the sale of these products to the Greek clientele was substantial, especially during the War of the Second Coalition (1798-1802). When exports of doubleheaded eagle jugs to the Habsburg Empire collapsed, the trade with the Greek clients enabled the firms to survive. ${ }^{28}$ However, the outbreak of the Greek war of independence in 1821 also dealt a major blow to trade activities between the eastern ports of Italy and those of the Epirus coast, causing substantial losses to the Pesaro producer. ${ }^{29}$ In the height of these exchanges, during the last decades of the eighteenth century and in the beginning of the nineteenth, Greek merchants, when returning from trade visits to Italy and especially from the Senigallia fair, would bring back novelty items, described as "conveniences of the European life."30 Since Pesaro-manufactured jugs with Italian inscriptions had existed earlier, it is claimed that Greek merchants were inspired by them to commission similar jugs with inscriptions in their own language. These were not marketed widely but were made-to-order for specific customers, Epirote merchants primarily from the communities of Ioannina and Kalarrytes, localities which were renowned for their prosperity and sumptuous ways of life. ${ }^{31}$

According to a contemporaneous Italian commentator, the jugs under discussion were "vulgar and a dime a dozen." 32 This comment reflects the fact that these artifacts were not considered works of art but rather common items for everyday use. At the same, it is acknowledged that these products would cater to the particular needs of a target group of buyers living in Epirus. ${ }^{33}$ In that market, they would be used for both "luxurious use" as well as for "decoration." ${ }^{34}$ Such contradictory references suggest a hybrid character of the items; although they were not valuable per se, they could be considered luxurious in a certain sense, as they were specially commissioned, and their customization indicated the heightened social status of the commissioner. Despite its humble nature

27 Lambros, "Peri Ipeirotikon Enepigrafon Mastrapadon," 270; and Grazia Biscontini Ugolini, Ceramiche pesaresi dal XVIII al XX secolo (Bologna, 1986), 122. On the Senigallia fair, see: Olga Katsiardi-Hering, Lismonimenoi Orizontes Ellinon Emporon: To Panigyri sti Senigallia (180s—arches roou aiona) (Athens, 1989).

28 Leon Lorenzo Loreti, "Maioliche Pesaresi del '700," in Maioliche del '70o Tra Urbania e Pesaro: catalogo della mostra, ed. Corrado Leonardi (Urbania, 1987), 28.

29 Loreti, Maioliche e terraglie, 6o.

$30 \quad$ Lambros, "Peri Ipeirotikon Enepigrafon Mastrapadon," 269.

31 Ibid., 270-272. See also Risorgimento greco e filellenismo italiano, ed. Caterina Spetsieri Beschi and Enrica Lucarelli (Rome, 1986), 204-207.

32 Korre-Zografou, Ta Kerameika, 127.

33 Ibid.

34 Lambros, "Peri Ipeirotikon Enepigrafon Mastrapadon," 269. 
and its unremarkable quality, the jug could signify the wealth and status of its owner, especially when personalized through one's initials or when owned in large quantities. ${ }^{35}$ Indeed, among the imports of pronounced luxuries such as Venetian and Bohemian glass or French porcelain, the Pesaro-made Epirote jug stands as an exemplary item of quantity production. Despite the fragility of the material, a substantial number of these items have survived, attesting to the large-scale nature of the production process. [Figure 4] Nevertheless, the personalized attributes add a dimension of exclusivity.

Nowadays, the majority of surviving Pesaro-made Epirote jugs with Greek verses are kept and exhibited in various museums and collections in Greece: several at the Benaki Museum (Athens), several others at the National Historical Museum (Athens and Hydra island), at the Museum of the Pre-Revolutionary Period (Ioannina), at the Averoff Collection (Metsovo), as well as in other private collections. Further items are held in other countries, for example at the Museo Civico (Pesaro), the Museo Internazionale delle Ceramiche (Faenza), the British Museum (London), and in private collections. ${ }^{36}$ These artifacts are valued by collectors and appear regularly in auctions, achieving high prices. ${ }^{37}$ Their present status as collectibles of substantial value emphasizes the range of possible meanings an object may carry. These meanings cannot be predicted; they are characterized by fluidity and constant negotiation by relevant stakeholders within a variety of social, financial, and other contexts.

35 A 1756 inventory from a wealthy household of Ioannina records "a hundred Ancona jugs; various Bohemian glassware-15o," Konstantinos D. Mertzios, "To en Venetia Ipeirotikon Archeion," Ipeirotika Chronika 11 (1936): 312. It is plausible that the term "Ancona" is used in this inventory to signify Pesaro-made jugs too, as they were typically exported to Epirus from the port of Ancona. Given the early date of this inventory, before the establishment of the Casali and Callegari firm which presumably first created the jugs with Greek verses, we may assume that these hundred jugs were of a similar form but without the Greek verses.

36 Giovanni Conti, L'Arte della Maiolica in Italia (Milano, 1973); Loreti, Maioliche e terraglie, xli; Maria Lada-Minotou, "Antikeimena Istorimena me Ellinika Themata," 234-236; and Natalia Vogeikoff-Brogan, "Skyromania? American Archaeologists in 193os Skyros," https:// nataliavogeikoff.com/2016/o6/o1/skyromania-american-archaeologists-in-193os-skyros/ (accessed August 9, 2019).

37 The Christie's Interiors-Master \& Makers auction (Sale 5205) of February 25, 2014 in London included an Ignazio Callegari (early nineteenth century) jug with Greek verses. The sale estimate was 1,00o to 2,00o British pounds; the jug was finally sold for 1,125 British pounds. Two similar items were sold in an auction of 27 February 2003. http://www .christies.com/lotfinder/Lot/a-pesaro-fabbrica-ignazio-callegari-maiolica-jug-5769014 -details.aspx (accessed August 9, 2019). 


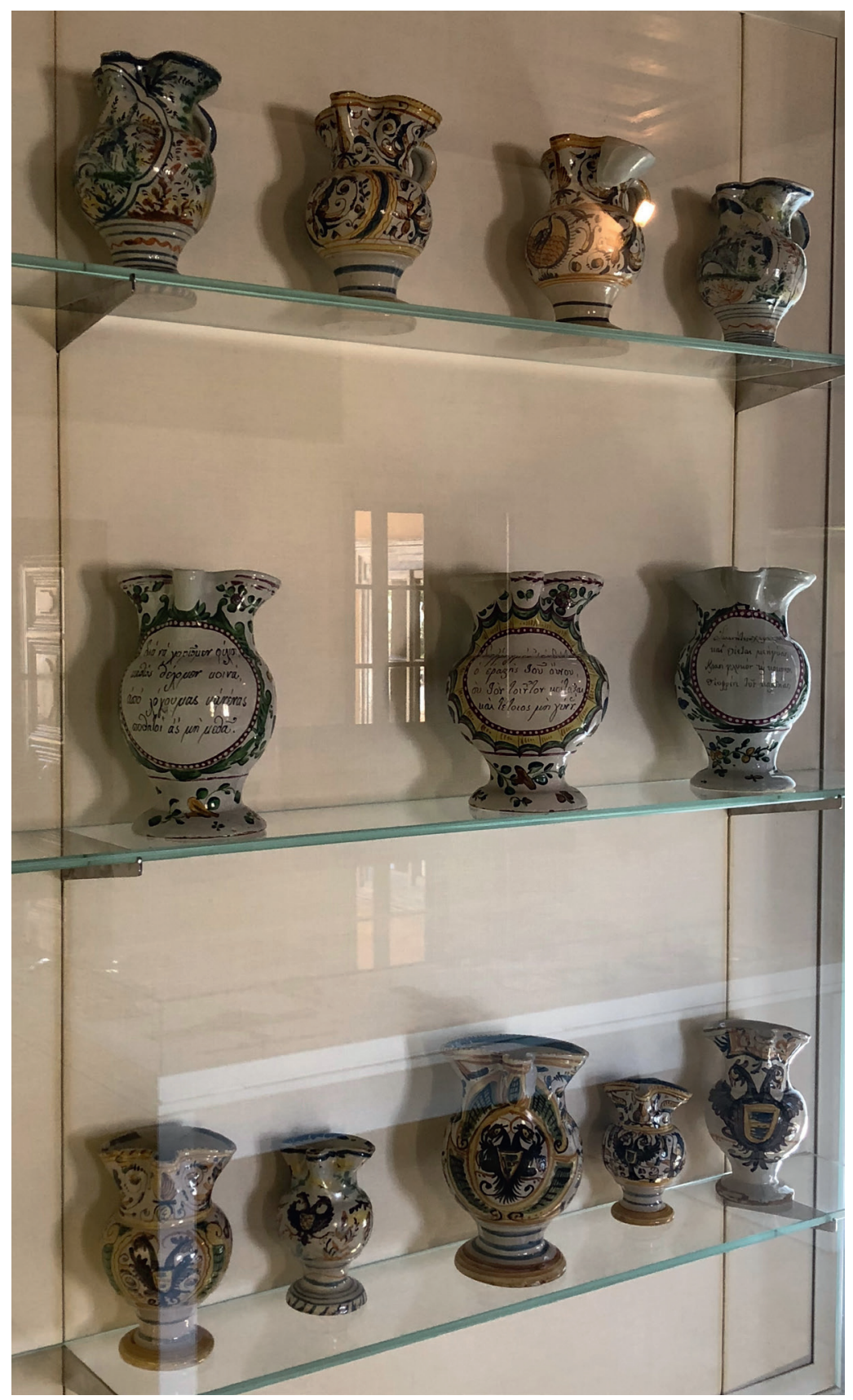

FIGURE 4 Several Pesaro-made trefoil jugs exhibited at the Lazaros Koundouriotis Historical Mansion (National Historical Museum), Hydra. PHOTOGRAPH BY THE AUTHOR. 


\section{The Commissioning Users in Context}

Tracing the social standing and activities of the people who acquired the Pesaro jugs with Greek verses enables us to gain a deeper understanding of the context in which these artifacts were produced, circulated, and used. The Greek merchants from Epirus who presumably ordered these jugs may be discussed within the wider framework of the activities and role of the "Balkan Orthodox merchant," whose fundamental role in the processes of circulation of products and ideas between the Ottoman Empire and the West has been duly emphasized..$^{38}$ The gradual expansion of Greek Orthodox merchants beyond local trade and their penetration into export markets has been described as "the most characteristic event in Ottoman-dominated Greece during the eighteenth century."39 Especially towards the end of the century, major political events such as the Russo-Ottoman treaty of Küçük Kaynarca in 1774, the opening of the Black Sea to foreign navigation in 1783, and later the Napoleonic Wars (1803-1815) facilitated the economic expansion of Greek traders. ${ }^{40}$ The shifts caused in the region's power balance by the aforementioned political developments benefited in particular certain local communities, "especially Greek and other Balkan merchants who already participated in a thriving trade with central Europe." ${ }^{\text {"1 }}$ As a result, a "commercial bourgeoisie materialized as minority merchants engaged in trade with the West under the legal protection of major western powers." These commercially-oriented Christian groups developed and thrived alongside a Muslim bureaucratic bourgeoisie. ${ }^{42}$ Arguably, the power emanating from the burgeoning foreign trade operated by predominantly non-Muslim and foreign merchant groups, as well as the respective expansion of the circulation of goods, were challenging the

38 See the classic study by Traian Stoianovich. "The Conquering Balkan Orthodox Merchant," The Journal of Economic History 20, no. 2 (1960): 234-313; and Fatma Müge Göçek, East Encounters West: France and the Ottoman Empire in the Eighteenth Century (New York, 1987).

39 Serapheim Maximos, I Avgi tou Ellinikou Kapitalismou: Tourkokratia, 1685-1789 (Athens, 2008), 108.

40 Sophia Laiou, "The Ottoman Greek 'Merchants of Europe' at the Beginning of the 19th Century," in Festschrift in Honor of Ioannis P. Theocharides. Studies on the Ottoman Empire and Turkey, vol. 2, ed. Evangelia Balta, Georgios Salakidis, and Theoharis Stavrides (Istanbul, 2014), 313.

41 Edhem Eldem, "Capitulations and Western Trade," in The Cambridge History of Turkey, vol. 3, ed. Suraiya Faroqhi (Cambridge, 2008), 323 .

42 Fatma Müge Göçek, Rise of the Bourgeoisie, Demise of the Empire: Ottoman Westernization and Social Change (New York, 1996), 44-45. 
economic, social, and political status quo. ${ }^{43}$ The gradual rise in the mercantile and shipping activity of the Ottoman Greeks reached its apogee between 1780 and 1820, when non-Muslim Ottoman merchants acquired economic and social privileges which allowed them more "freedom in their social behavior, as demonstrated especially in their attire and their consumption of foodstuffs." 4 In this context, Greek merchants played the all-important intermediary role between European powers and the Ottoman world which resulted in substantial financial prosperity for themselves and enabled their incorporation into the wider system of division of labor. ${ }^{45}$

Such positive and significant developments have been largely neglected or ignored until recently by Greek historiography, which bypassed "the 'dark age' of subjection to Ottoman rule under the telling term of Tourkokratia [Turkish rule]."46 During the nineteenth and twentieth centuries, Greek historiography developed the perception of a "non-historical dark age of an undifferentiated and opaque Tourkokratia," which transformed the Greek presence under the Ottomans into "a discourse of proto-national victimization and martyrology."47 Moreover, this one-sided view has been exploited as an instrument for nationbuilding and for creating a more attractive national history, indeed a mythology with great appeal to the public. New research has gradually been leading to a more complex and nuanced understanding of the condition of non-Muslim subjects in the Ottoman Empire. ${ }^{48}$ Arguably, although the Greek populations were in a subservient position, often experiencing great insecurity, recent historiography tends to emphasize the consensual nature of the Ottoman ruling system. The latter was a relatively stable structure of power that was not complacent, but at the same time was not founded on direct and continuous violence; its stability was emanating from the subjects' consent. This did not reflect an ideal co-existence of different cultures but the balance of power relations which included the exertion of violence, when necessary ${ }^{49}$ Furthermore, relative social and intellectual stagnation did not necessarily mean material deprivation. ${ }^{50}$

43 Donald Quataert, "Clothing Laws, State, and Society in the Ottoman Empire, 1720-1829," International Journal of Middle East Studies 29, no. 3 (1997): 408-410.

44 Laiou, "The Ottoman Greek 'Merchants of Europe'," 315.

45 Maximos, I Avgi, 49.

46 Edhem Eldem, "Greece and the Greeks in Ottoman History and Turkish Historiography," The Historical Review/La Revue Historique 6 (20o9): 33.

47 Ibid., 37.

48 Alkis Angelou, To Kryfo Scholeio: To Chroniko enos Mythou (Athens, 2007); and idem, Mythoi kai Ideologimata sti Synchroni Ellada (Athens, 2007); Eldem, "Greece and the Greeks," 40. Pizanias, I Istoria ton Neon Ellinon, 53-55 and 99. Ibid., 132. 
Thus, the aforementioned political developments in the second half of the eighteenth century led to an expansion of trade in the south Balkan area and generated economic growth, despite the restrictive and highly regulated environment. The prosperity resulting from increased trade activities went hand in hand with and underpinned the emergence of a Greek bourgeois class, particularly on the northwestern mainland, the Aegean islands, and the cities of Constantinople (Istanbul) and Smyrna (Izmir), namely the regions where the major hubs of commercial activities were situated. Commerce on land and sea led to the development of education, the emergence of new professions, the establishment of technical guilds, and to other bourgeois activities. ${ }^{51}$ These phenomena reflected the differentiation of Greek bourgeois social strata, of a distinct Greek "European world" within Ottoman society. ${ }^{52}$ The economic power of this rising Greek bourgeoisie was combined with deepening ties with Europe, intellectual growth, increased confidence and extroversion, and the strengthening of a distinct identity. ${ }^{53}$ Among the expressions of this new identity was the acquisition and enjoyment of material wealth, including luxury objects. ${ }^{54}$

The long eighteenth century was, therefore, a time of financial growth and cultural bloom for some Greek communities in the context of Ottoman rule. The associated emergence of the Greek bourgeoisie is embedded in the historical phenomenon of the "Neo-Hellenic Enlightenment." Influenced by the wider philosophical and intellectual movement of the Enlightenment in eighteenth-century Western Europe, the Neo-Hellenic Enlightenment was directly related to the rise of the local merchant class and encompassed the belief in rationalism, self-improvement, and the pursuit of happiness; by opening up new horizons and offering novel perspectives to the Greek populations, it also directly affected their understanding of their material conditions: their clothing, furnishings, and other possessions. Novel material manifestations reflected the awareness of new possibilities of self-realization and suggested the idea of freedom, both on a personal and a collective level. ${ }^{55}$

\footnotetext{
$5^{1} \quad$ Ibid., 422.

$52 \quad$ Ibid., 431.

53 Ibid., 426-432. See also Thomas W. Gallant, The Edinburgh History of the Greeks, 1768 to 1913: The Long Nineteenth Century (Edinburgh, 2015), 24-50.

54 Göçek, Rise of the Bourgeoisie, 105-110. See also Artemis Yagou, "A Dialogue of Sources: Greek Bourgeois Women and Material Culture in the Long 18th Century," in Women, Consumption, and the Circulation of Ideas in South-Eastern Europe, 17th-19th Centuries, ed. Constanța Vintilă-Ghițulescu (Leiden, 2017), 95-123.

55 K. Th. Dimaras, Neoellinikos Diafotismos (Athens, 1977). Following the intellectual tradition established by Dimaras, the Neo-Hellenic Enlightenment is considered "a local manifestation of the overall European enlightenment," Vassilis Panayotopoulos, "I Afosiomeni tou Ellinikou Diafotismou," in: Aikaterini Koumarianou, Anthropoi kai
} 
The town of Ioannina and nearby communities in the region of Epirus held a key position in these transformative processes. Ioannina, the largest town in the homonymous administrative division, was an important regional center with a strong handicraft sector, especially in the areas of metalwork and textiles, as well as a commercial node on the crossroads connecting the Ottoman Empire with parts of Europe. ${ }^{56} \mathrm{~A}$ commentator goes as far as to say that "Epirus became the frontier at which the Ottomans met Europe." 57 Admittedly, the social and financial conditions in Epirus in the decades around the turn of the nineteenth century cannot be discussed without reference to the crucial role of Ali Pasha of Ioannina, the regional ruler from 1788 to 1822. Ali Pasha (circa 1744-1822) was a dynamic and controversial personality with exceptional leadership skills. Substantial financial and cultural exchanges between him and his Greek subjects did not necessarily protect them from his brutality. Arguably, a precarious balance had to be struck by the Christian populations, especially the wealthier ones, whose actions and lifestyle might appear provocative. ${ }^{58}$

Merchants originating from Epirus had been active in trade with the ports of Ancona and Venice (already since the sixteenth century) and had established prosperous diasporic communities in Italy. These communities gradually experienced a break with traditional ways of living, a break which had two aspects: a material one, through the acquisition and accumulation of European goods such as domestic equipment, jewelry, and garments; and, on the other hand, a psychological and ideological one, as Europeanized and cosmopolitan

Idees: Keimena gia ton Diafotismo kai ton Elliniko Kosmo: 180s-19os Aionas (Athens, 2013), 17. Furthermore, it is argued that "the Greek Enlightenment should not be understood first and foremost as the product of either alienation from or marginalization within the empire. Instead it reflected the confidence of a community that felt secure enough to take up the task of tending to its own garden." Molly Greene, The Edinburgh History of the Greeks, 1453 to 1768: The Ottoman Empire (Edinburgh, 2015), 213. The connection of this quote to Voltaire's Candide (1759) is obvious.

56 Other Epirote communities such as Kalarrytes, Syrrako, and Metsovo, with predominantly Vlach-speaking populations, enjoyed some privileges and were also thriving. Evangeli A. Datsi, Ta Isnafia mas ta Vasilemena: Ta Giannina ton Mastoron kai ton Kalfadon (Athens, 2006); Marina Vrelli-Zachou, "Ta Ipeirotika Kosmimata: Istoria-Laografia," Eikastiki Paideia 24 (2008): 94-105; and Fanis Michalopoulos, Moschopolis: Ai Athinai tis Tourkokratias (Athens, 1941), 15. Kalarrytes and Syrrako in particular were allegedly the loci of extravagant lifestyles. Lambros, "Peri Ipeirotikon Enepigrafon Mastrapadon," 270.

57 Roderick Taylor, Embroidery of the Greek Islands and Epirus (New York, 1998), 128.

58 There is a rich and growing bibliography on the impact of Ali Pasha in the region's history. For a recent overview, see Panagiotopoulos, Archeio Ali Pasa, vol. 4, 120-121. Additionally, see: Katherine E. Fleming, The Muslim Bonaparte: Diplomacy and Orientalism in Ali Pasha's Greece (Princeton, 2014). 
lifestyles were adopted. ${ }^{59}$ Resulting from the close links and intense communication between the diasporic communities and the homeland, a middle-class gradually emerged in towns like Ioannina. New objects, habits, and mentalities mingled to create a new awareness. ${ }^{60}$ In Ioannina, described in recent historiography as "the city of the Greek Enlightenment," ${ }^{11}$ a new ethos became more and more visible and appeared threatening to Christians and Muslims alike. Luxurious dressing habits, attitudes unseen before, and liberal morals echoing the standards of European cities reached the local populations, shook the foundations of the traditional status quo and set the tone for the approaching changes. ${ }^{62}$ Greek Epirote merchants were taking advantage of new luxuries and, through consumption, sought to express themselves and assert their individuality. Despite consumption limitations imposed on subjects of the Ottoman Empire, such as through sumptuary laws, ${ }^{63}$ in the entire eighteenth century the empire was marked by a shift towards leisure and consumption, a shift which involved in different ways and degrees the sultanic household, the imperial elite, a predominantly Muslim bureaucratic apparatus, and nonMuslim merchant communities. ${ }^{64}$

Within this context, the Pesaro jug with Greek verses offered its commissioners and buyers the opportunity to customize a rather humble object and elevate it to a manifestation of joie de vivre and self-assertion, even provocation. The act of wine drinking further emphasizes the nature of the jugs as markers of differentiation from the Muslim population and an expression

59 For the range and impact of diasporic Greek communities all over Europe, see Olga Katsiardi-Hering, "I Elliniki Diaspora: To Emporio os Genikevmeni Ethniki Exeidikefsi," in Istoria tou Neou Ellinismou, vol. 1, ed. Vassilis Panagiotopoulos (Athens, 2003), 87-112. Mobility was a crucial factor of innovation in the eighteenth century and the emergence of portable consumer objects was one aspect of these phenomena, Gianenrico Bernasconi, Objets Portatifs au Siècle des Lumières (Paris, 2015), 30.

6o Eleni Kourmantzi-Panagiotakou, I Neolliniki Anagennisi sta Giannena: Apo ton Paroiko Emporo ston Athanasio Psalida kai ton Ioanni Vilara (17os-arches 19ou aiona) (Athens, 2007), 23-30. A characteristic example of the emerging realities is provided by the Maroutsi family, who had established strong commercial networks between Ioannina and Venice and who imported a variety of luxury items (such as glass vessels, mirrors, and books), both for purposes of trade and for use in their Ioannina mansion. Konstantinos D. Mertzios, Mnimeia Makedonikis Istorias (Thessaloniki, 2007). This case deserves further research.

61 Panagiotopoulos, Archeio Ali Pasa, vol. 4, 112.

62 Ibid., 124-125.

63 Donald Quataert, "Clothing Laws," 403-425; and Madeline C. Zilfi, "Goods in the Mahalle: Distributional Encounters in Eighteenth Century Istanbul," in Consumption Studies and the History of the Ottoman Empire, 1550-1922: An Introduction, ed. Donald Quataert (New York: 2000), 289-311.

64 Quataert, "Clothing Laws," 409-410. 
of enjoyment even under difficult circumstances. ${ }^{65}$ Although "allowed to drink at home or at private gatherings, non-Muslims were prohibited from consuming wine in public. Periodically, the central government imposed severe restrictions on consumption of wine as a means of displaying its power and authority and as a preemptive measure against social disorder." ${ }^{6}$ In reality, "stricter and more tolerant periods went in cycles; nevertheless, non-Muslims would drink enthusiastically during festivals and fairs." 67 The communal character of wine-drinking sprees also points to the performative value of a jug used in such gatherings, as owning and using this object would enable an individual to assert his identity among a group of friends, peers, or even competitors. It appears then that, despite its modest nature, the ceramic jug with Greek verses incorporates a range of meanings that would normally be reserved for exclusive items of special value. This observation leads to a discussion of the concept of luxury and its evolving meaning in early modern Europe.

\section{The Trefoil Jug with Greek Verses as Popular Luxury}

In the long eighteenth century, a number of artifacts, including the jugs under discussion, were sold to Greek clients who used them to decorate their prosperous households and thus became "luxury equipment of frequent use." 68 This is a telling expression, suggesting that the distinction between exclusive, exceptional luxury items and objects of everyday use becomes blurred. Is it then possible to define "degrees" or "grades" of luxury in the Greek context of the long eighteenth century? This question leads to a discussion of the concept of luxury and its meaning for the Greek populations under the Ottoman rule. Although

65 See for example the verses written on a trefoil jug and stating that "Turks do not drink wine, while Greeks (Romei) do," in Lambros, "Peri Ipeirotikon Enepigrafon Mastrapadon," 271.

66 Mehrdad Kia, Daily Life in the Ottoman Empire (Santa Barbara, 2011), 242.

67 Suraiya Faroqhi, Subjects of the Sultan: Culture and Daily Life in the Ottoman Empire (London, 2015), 215. On the complex and often contradictory stance of the Ottoman Empire towards alcohol, see also: Vjeran Kursar, "Their God is their Belly, Their Mother is their Drunkenness': Bosnian Franciscans on Alcohol Consumption in Ottoman Bosnia," in: Arkadiusz Blaszczyk and Stefan Rohdewald, eds., From Kebab to Ćevapčići: Foodways in (Post-)Ottoman Europe (Wiesbaden, 2018), 144-161.

68 Kyriazopoulos and Charitonidou, "Poterie de Pesaro," 353. See also: Basile Kyriazopoulos and Angele Charitonidou, "Italikoi Mastrapades me Ellinika Stichoplakia," in Praktika-4. Symposio Laografias tou Voreioelladikou Chorou, Ioannina, 10-12 Oktovriou 1979 (Thessaloniki, 1983), 83-125; and Basile Kyriazopoulos, Ellinika Paradosiaka Kerameika (Athens, 1984). 
the Greeks of Istanbul sought primarily to imitate the Ottoman administrative and Phanariot elites, there was a gradual shift, especially by intellectuals and merchants of the diaspora, towards western European cultural influences. ${ }^{69}$ In this vein, we recognize in the case of the Pesaro jugs a type of luxury that was not looking to Ottoman dignitaries for inspiration but was rather directed towards European models that the merchants had encountered through direct experience during their travels. The new types of luxuries and consumption practices of wealthy merchant families in Greek provincial towns like Ioannina were directly influenced by their strong diasporic connections; they may be better understood by comparing them to similar developments in western Europe.

In the late eighteenth century, the world became a smaller place; networks of communication were becoming much more intertwined through travel and exchange, through the movement of individuals, commodities, and ideas. The porousness of borders and the vitality of zones of contact and exchange enabled the dynamic circulation of people, things, and ways of thinking. ${ }^{70}$ The decades on either side of 1800 were "truly a seed-time of the modern world." ${ }^{71}$ In that period, the concept of "industrious revolution," as defined by economic historian Jan de Vries, acquired crucial importance. ${ }^{72}$ This phenomenon, which unfolded gradually after 1650, "linked an intensification of labor and the accumulation of consumption capital to new consumer aspirations, what contemporaries called an 'awakening of the appetites of the mind'." 73 The concept of the industrious revolution may be employed as a foundation to interpret various economic, social and cultural developments in that period. In a variety of different locations over the world, small-scale technological innovations went hand-in-hand with modifications in the distribution of goods and eventually in people's material habits, leading people to want food and clothing of higher quality, more honor, and elevated social status. People's horizons of desire changed as information about lifestyles and consumption habits of ruling and elite groups was circulating faster. Non-elite groups wanted to emulate them and, like them, represent themselves in more pleasing and persuasive ways. This conceptual shift empowered shopkeepers and retailers, generated

\footnotetext{
69 Julia Chatzipanagioti-Sangmeister, "Chrysa Siritia kai Balomena Papoutsia: O Logos peri Modas ston Neoelliniko Diafotismo," Ta Historika, 62 (2015): 55-80.

70 David Blackbourn, "Germany and the Birth of the Modern World," Bulletin of the German Historical Institute 51 (2012): 9-11.

71 Ibid., 10.

72 Jan de Vries, The Industrious Revolution: Consumer Behaviour and the Household Economy, 1650 to the Present (Cambridge, 2008).

73 Ibid., 268.
} 
new demands for labor and increased the appeal of luxuries from distant places. ${ }^{74}$ Between the end of the seventeenth century and the beginning of the nineteenth, new patterns of demand were directed towards a range of consumer goods, a situation which was best observed in northwestern Europe, particularly England, the Low Countries, and parts of France and Germany. Eastern Europe and the Mediterranean zones exhibited some of its features, although they did not participate fully in its main developments. ${ }^{75}$ Recent studies document specific examples of similar patterns of changing attitudes in relation to leisure and sociability observed in the Ottoman Empire. ${ }^{76}$

The phenomenon of the industrious revolution led to the creation of a "new" material culture, with "new luxuries" having a different set of characteristics from the "old luxuries." Durability and intrinsic value declined in importance relative to the use of novel and less durable materials that were cheaper and more accessible. The design of everyday items became more significant; textiles and other household objects were marketed in an increasing range of different styles, colors, and formats. Variety and customization became more and more important, as consumption was "entwined with an individual expression of the self."77 "Semi-luxury" or "popular luxury" goods constituted a new form of merchandise which was reaching consumers through a variety of channels, including the manufacturer and the street seller. It was not the absolute value or high quality of these goods that made them precious, but their symbolic role. They represented an escape from basic needs and the importance of the unnecessary, which was a source of great pleasure. Pleasurable uses could be realized with inexpensive materials: cotton instead of silk and earthenware instead of porcelain answered the increasing demand for differentiation and customization. Novelty did not necessarily mean scarce and expensive goods for the elites and enabled a blurring of social boundaries, as non-elites could also access novel items. ${ }^{78}$ Additionally, portable objects were

74 Christopher A. Bayly, The Birth of the Modern World, 1780-1914 (Oxford, 2004), 6.

75 de Vries, The Industrious Revolution, xi-xii.

76 James Grehan, "Smoking and 'Early Modern' Sociability: The Great Tobacco Debate in the Ottoman Middle East (Seventeenth to Eighteenth Centuries)," The American Historical Review 111, no. 5 (2006): 1352-1377; and Shirine Hamadeh, The City's Pleasures: Istanbul in the Eighteenth Century (Seattle, 2007).

77 Bruno Blondé and Ilja Van Damme, "Fashioning Old and New or Moulding the Material Culture of Europe (Late Seventeenth-Early Nineteenth Centuries)," in Fashioning Old and New: Changing Consumer Patterns in Western Europe (1650-1900), ed. Bruno Blondé et al. (Turnhout, 2009), 2.

78 Natacha Coquery, "The Semi-luxury Market, Shopkeepers and Social Diffusion: Marketing Chinoiseries in Eighteenth-Century Paris," in Blondé et al., Fashioning Old and New, 121-131. 
used as crucial props in the performance of elegance that had become "the benchmark of social and cultural superiority."79

In this vein, we argue that, notwithstanding substantial differences between various socioeconomic contexts, the groundbreaking concept of the industrious revolution may be applied with reference to the activities of the "conquering Balkan Orthodox merchant." The trefoil Pesaro jug with Greek verses, although humble and of low absolute value, was a material manifestation of new forms of production, consumption, and circulation of goods, as well as of new mentalities of consumption and self-expression on a regional level. ${ }^{80}$ Greek merchants who traveled regularly outside the Ottoman Empire became aware of and experienced new realities. As traders who frequented international fairs and encountered foreign merchants, they would have a good understanding of the range of goods available in the European market for non-elite groups and of the significance of affordable novelties available in such markets. Having acquired a certain financial standing through their ingenuity and hard work, they would desire to participate themselves in the new consumer world. It is important to highlight that, according to a recent analysis, work was precisely the factor that differentiated these middle-class merchant groups from the various central or regional elites, who abstained from and despised work. The power of these middle classes was not emanating from hereditary rights or from conquest; it was a direct result of their own commercial endeavors, and therefore work could be seen as a foundation and core element of their identity. ${ }^{81}$

Furthermore, the Pesaro jug with Greek verses is an example of two-way circulation of goods and ideas, where the individual is inspired by external factors but does not imitate blindly. The actors, i.e. Greek merchants who directly commissioned these customized products, do not appear as passive subjects but as knowledgeable, confident and proactive consumers who wish

79 Ariane Fennetaux, "Toying with Novelty: Toys, Consumption, and Novelty in EighteenthCentury Britain," in Blondé et al., Fashioning Old and New, 24.

80 The Pesaro trefoil jug with Greek inscriptions complies with the definition of "populuxe" products: "Bought for their appeal and innovation, these items entailed a certain degree of skill, but not necessarily extensive financial investment in fixed capital for their manufacture. Most such objects could be purchased ready-made, although they could be customized (as in the case of expensive coaches or much cheaper sets of china plates). Their main difference compared to 'undifferentiated' products is that they were marketoriented ready-made products, conscious of the variations and vagaries of fashion, conspicuous consumption, and consumer whimsy," see: Giorgio Riello, "Strategies and Boundaries: Subcontracting and the London Trades in the Long Eighteenth Century," Enterprise \& Society 9, no. 2 (June 2008): 264.

81 Pizanias, I Istoria ton Neon Ellinon, 438-439. 
to assert themselves. Despite limitations that the Greek merchants experienced as subjects of the Ottoman Empire, they were at the same time keen to generate expressions of self-affirmation and self-fashioning and to make a personal imprint on their environment. Moreover, shaping their individual identity through the acquisition of personalized jugs was embedded within the communal, as these artifacts were intended for use during group rituals such as drinking feasts. Beyond an expression of individual financial success and heightened social status, these objects would be testimonies to male companionship and to a strong group identity. Last but not least, the nexus of personal and collective manifestations incorporated in these objects had strong political connotations and pointed to a world that was in the process of gradual and, at the same time, radical transformation. ${ }^{82}$

\section{Conclusion}

The Pesaro-made Epirote trefoil jug with Greek verses, which was produced, circulated, and used in the late eighteenth and early nineteenth centuries, is a hybrid object condensing a wide range of financial and cultural interactions. A case of made-to-order quantity production for the emerging Greek merchant middle class under Ottoman rule, it illustrates the power of humble things to represent novel ideas and to express diverse historical forces in

82 Mundane, everyday consumer objects with political messages may be found in many different contexts during the same time-period. The following three examples are particularly relevant to the present case-study: a) Small, brightly colored teapots with the message "No Stamp Act" were produced in the 176os by English potters and exported for American colonial consumers who were organizing resistance to parliamentary taxation without representation, Timothy H. Breen, How Consumer Politics Shaped American Independence (Oxford, 2004), xii-xiv. b) A teapot produced in England in the 1760s bears the number 45 hidden under the spout. The number 45 became shorthand for expressing radical and anti-monarchist sympathies, as it referred to the issue number of the newspaper The North Briton in which King George III and his parliamentary allies were severely criticized. John Wilkes, a radical politician and publisher of the newspaper, was expelled from parliament, convicted of sedition and forced into exile, Ian Hislop and Tom Hockenhull, I Object: Ian Hislop's Search for Dissent (London, 2018), 129-132. c) An earthenware plate depicting the slogan "Vive la liberté" held up by two crossed tricolor flags and crowned by a laurel wreath was produced in Nevers (France) in the late eighteenth century. Such an object "would have enabled either a modest household to be reminded of and display republican sentiments or a wealthier one to inhabit a more egalitarian interior," Leora Auslander, "Beyond Words," The American Historical Review 110, no. 4 (October 2005): 1030-103. 
the form of a single artifact. The status of the vessel as popular luxury arises from the social practices in which it is embedded. The Greek verses inscribed on the artifact transform it into a statement of the owner's identity and his social, cultural, and political aspirations. A manifestation of personalized consumption, the jug serves as an indication of an emerging bourgeois identity and exemplifies a new awareness of the role of the individual in the public sphere.

\section{Acknowledgement}

The research leading to this publication was partially funded by the project Luxury, Fashion and Social Status in Early Modern South-Eastern Europe (LuxFaSS), financed by the European Research Council (ERC-2014-CoG no. 646489) and hosted by New Europe College - Institute for Advanced Study (Bucharest). 